\title{
Article \\ The Effect of Microbial Inoculation under Various Nitrogen Regimes on the Uptake of Nutrients by Apple Trees
}

\author{
Kamila Łucja Bokszczanin *, Dariusz Wrona (D) and Sebastian Przybyłko (D) \\ Department of Pomology and Horticulture Economics, Institute of Horticultural Sciences SGGW, \\ Nowoursynowska 159 Street, 02-787 Warsaw, Poland; dariusz_wrona@sggw.edu.pl (D.W.); \\ sebastian_przybylko@sggw.edu.pl (S.P.) \\ * Correspondence: kamila_bokszczanin@sggw.edu.pl
}

check for updates

Citation: Bokszczanin, K.Ł.; Wrona, D.; Przybyłko, S. The Effect of Microbial Inoculation under Various Nitrogen Regimes on the Uptake of Nutrients by Apple Trees. Agronomy 2021, 11, 2348. https://doi.org/ 10.3390 /agronomy11112348

Academic Editors: Othmane Merah, Purushothaman Chirakkuzhyil Abhilash, Magdi T. Abdelhamid, Hailin Zhang and Bachar Zebib

Received: 1 September 2021

Accepted: 15 November 2021

Published: 19 November 2021

Publisher's Note: MDPI stays neutral with regard to jurisdictional claims in published maps and institutional affiliations.

Copyright: (c) 2021 by the authors. Licensee MDPI, Basel, Switzerland. This article is an open access article distributed under the terms and conditions of the Creative Commons Attribution (CC BY) license (https:/ / creativecommons.org/licenses/by/ $4.0 /)$.
Abstract: The European Green Deal strategy currently implemented in the EU aims to, among others, reduce the negative impact of fertilization on the environment. One of the solutions influencing the nutritional status of plants and the improvement of soil quality is the use of plant symbiosis with microorganisms. Thus, in this study we investigated the effect of arbuscular mycorrhizal fungi (AMFs) and plant-growth-promoting rhizobacteria (PGPR) colonization on the nutritional status of apple leaves and fruit, depending on the nitrogen treatment. In a fully factorial experiment, trees were grown for nine years with or without AMFs and PGPR. We compared several ammonium nitrate treatments as well as growth without fertilization as a control. The interactions between inoculation and doses of nitrogen fertilization were observed. AMF + PGPR significantly increased the concentration of nitrogen $(\mathrm{N})$, phosphorus $(\mathrm{P})$, and potassium $(\mathrm{K})$ in leaves up to $5 \%, 23 \%$, and $19 \%$, respectively, depending on the $\mathrm{N}$ dosage. Conversely, in uninoculated trees, the nitrogen treatment had a negative impact on the leaf P mineral status. On the other hand, under microbial inoculation conditions, the dose of $100 \mathrm{~kg} \mathrm{~N} \cdot \mathrm{ha}^{-1}$ diminished the leaf phosphorus content in comparison to other $\mathrm{N}$ doses, by a maximum of $9.6 \%$. AMF + PGPR, depending on the $\mathrm{N}$ treatment, either did not influence or it decreased the $\mathrm{Mg}$ and $\mathrm{Ca}$ concentrations in the leaves by maximums of $8 \%$ and $15 \%$, respectively. Microbial inoculation had no effect on the acquisition of $\mathrm{Ca}$ and $\mathrm{Mg}$ by fruits, except for the coupled negative influence of the $100 \mathrm{~kg} \mathrm{~N} \cdot \mathrm{ha}^{-1}$ treatment. Symbiosis positively conditioned the K in fruits under a specific $\mathrm{N}$ regime- $100 \mathrm{~kg} \mathrm{~N} \cdot \mathrm{ha}^{-1}$ divided into two applications during the season and 50 $\mathrm{kg} \mathrm{N} \cdot \mathrm{ha}^{-1}$ applied to the herbicide strip, increasing the concentration by approximately $4 \%$ and $8 \%$, respectively. This study greatly contributes to our understanding of the benefits of AMF and PGPR on perennials and encourages the future exploration of their effects on apple yield and fruit quality.

Keywords: arbuscular mycorrhizal fungi; PGPRs; nitrogen fertilization; ammonium nitrate; leaf nutrient uptake; fruit nutrient uptake; mycorrhizal colonization

\section{Introduction}

The proper mineral nutrition of fruit plants determines the health, resistance, yield, and quality of fruit. The mineral nutrient that plants require the greatest amount of is nitrogen (N), and its availability is a major factor limiting plant growth in natural [1,2] as well as agricultural [3] ecosystems. Nitrogen enhances the metabolic processes that influence the physicochemical environment at the soil-root interface. It modifies rhizosphere conditions, interferes with the uptake of cations and anions, and enhances or represses the activity of several enzyme systems [4]. The need to fertilize with this component depends on the natural amount of nitrogen in the soil and different plant species' requirements. $\mathrm{N}$ management plays a very important role in determining apple yield and quality.

Currently, there is a trend to reduce nitrogen fertilization doses due to the deterioration of soil conditions and water pollution with nitrogen compounds. One of the main elements of the EU Biodiversity Strategy for 2030, in line with the European Green Deal, is the need 
to step up efforts to protect soil fertility and reduce soil erosion and the overuse of nutrients, while increasing levels of organic matter in the soil. This includes the target of reducing ammonia emissions by $21 \%$ by 2030 .

A decrease in the content of organic matter and $\mathrm{N}$ leakage from agricultural systems into groundwater, rivers, coastal waters, and the atmosphere have been observed for years [5]. Nitrate leaching and $\mathrm{N}_{2} \mathrm{O}$ emissions from agricultural soils are recognized by scientists, environmental groups, and policymakers as a major environmental threat [6-12]. Some studies show that the use of synthetic nitrogen fertilizers reduces soil organic matter (SOM) by increasing SOM mineralization $[13,14]$. This is particularly important in view of the observed decline in soil organic matter, while approximately $45 \%$ of soils in Europe are characterized by low or very low organic matter content. Organic matter is the basis of soil fertility, plays a key structure-forming function, and is the main source of food and energy for soil organisms that determine the biodiversity of the soil environment. Currently, research is being carried out on sustainable nitrogen fertilization, both synthetic and organic [15]. With the use of only mineral nitrogen fertilizers, the rate of organic matter mineralization increases, which leads to a decrease in the content of easily decomposed organic matter in the soil and a decrease in the microbial biomass content $[16,17]$. Many studies [18-20] have found that microbial biomass and microbial activity are closely related to the content of organic matter, which is positively influenced by organic substances, such as crop residues or manure. Therefore, it is important to find alternative ways to increase the nutrient content and organic matter content of soil. Organic fertilizers, mulching with organic matter, and the use of mycorrhizal fungi can be used for this purpose. Arbuscular mycorrhizal fungi improve resistance to biotic and abiotic stresses, and improve the absorption of minerals by plants. Preliminary scientific studies have provided evidence that the inoculation of young apple trees with AMFs can reduce the incidence of the fungal pathogens Dematophora necatrix (causing white root rot apple disease) and Botryosphaeria sp. [21,22] and improve seedling growth rates and nutritional status [23-27].

Arbuscular mycorrhizal fungi (AMFs) are soil fungi that form a mutualistic symbiosis with the roots of the majority of plant species, including many important crops [28,29]. AMFs are recognized as a major component in the functioning of agroecosystems [30]. As compensation for carbon, AMFs provide plants with essential nutrients-predominantly phosphorus-which they efficiently absorb from the soil via extensive networks of hyphae, thus potentially reducing the need for inorganic fertilizers [31]. In addition to nutrient provision, AMFs may also directly benefit crop species through increased resistance to biotrophic and necrotrophic pathogens, nematodes, and insects [32], tolerance to drought and adverse soil conditions [33,34], and a competitive ability over non-mycorrhizal plants [35]. They may indirectly benefit crops through improved soil structure [36] and plant nutrition by increasing the availability and translocation of various nutrients [37]. Despite the potential benefits, many factors can limit mycorrhizas and, thus, their use in modern agricultural systems. It was found that minimum tillage systems increase bacterial diversity by $7 \%$ and do not affect either soil total fungal diversity or AMF diversity compared to conventional tillage [38]. Moreover, it was shown that AMF diversity was reduced by $\mathrm{N}$ fertilization, supposedly due to a smaller investment in mycorrhizal symbioses by host plants [39] as well as a reduction in the $\mathrm{pH}$ induced by the addition of $\mathrm{N}$, which improves phosphorus $(\mathrm{P})$ availability $[38,40,41]$. Recent trends for the protection of the environment and the demand for healthy and ecologically produced food suggest minimal or no use of chemicals in agricultural production. Mycorrhizal fungi can promote plant root growth in marginally poor soils and under environmental stress. Mycorrhizal inoculation can contribute to the production of high-quality fruit trees with balanced mineral nutrient uptake [42,43].

Facing the challenges of organic fruit farming and balanced nitrogen fertilization, in our research, we hypothesized that in soil rich in organic matter, apple root mycorrhization and PGPR enhance nutrient uptake by the leaves and fruits of the apple trees regardless of $\mathrm{N}$ fertilization. Our research fills the knowledge gap regarding the simultaneous effect of 
nitrogen fertilization with AMF and PGPR on the nutritional status of apple trees, due to the limited available literature on this subject.

\section{Materials and Methods}

The trial was initiated in the spring of 2011 and covered nine growing seasons. It was conducted in the experimental orchard of the Warsaw University of Life Sciences, Wilanów, Poland (N 52 ${ }^{\circ} 36.1^{\prime \prime}$, E $\left.21^{\circ} 5^{\prime} 58.2^{\prime \prime}\right)$. The plant material consisted of apple Malus $\times$ domestica Borkh. cultivar 'Šampion Arno' grafted onto M.9 rootstock. Trees were planted in 2011 in $3 \times 1 \mathrm{~m}$ plots with deep, loamy alluvial soil with $2.5 \%$ humus. The trees were trained in a spindle-bush system. The floor management system in the orchard included turf grass in the alleyways that was mowed several times during the season, and a herbicide strip within tree rows with a soil width of $1 \mathrm{~m}$ that was sprayed with glyphosate using a commercially available Roundup $360 \mathrm{SL}$ formulation at a dose of $4 \mathrm{~L} \cdot \mathrm{ha}^{-1}$. The herbicide was used at the beginning of June and after fruit harvesting at the beginning of October in each year of the experiment.

The weather conditions during the course of the trial are presented in Figure A1. Data were collected during the experiment using the Davis Vantage Pro 7 field weather station (Davis Instruments, Hayward, CA, USA) installed in the experimental orchard.

The experiment was set up using a split-block design. The trees were planted in two separate rows, one of which was treated with microbial inoculum (M); the other was not inoculated (M0, control).

The trees were inoculated in field conditions. Commercially available microbial inoculum with a total concentration of $10^{6} \mathrm{CFU} \cdot \mathrm{g}^{-1}$ and containing ground and shredded roots of host plants with the spores and mycelium of arbuscular mycorrhizal fungi (AMFs), including Glomus mosseae GP11, G. viscosum GC41, and G. intraradices GB67, and plant-growth-promoting rhizobacteria (PGPR), including Bacillus subtilis BA41 and Streptomyces spp. SB19, formulated as a powder, was applied to the soil pits $30 \mathrm{~cm}$ deep during the tree planting at a dose of $10 \mathrm{~g} \cdot$ tree $^{-1}$. Then, in every year of the experiment, a dose of $2 \mathrm{~g} \cdot \mathrm{m}^{-1}$ of the inoculum was applied next to the trees, three times each season at 3-week intervals, with the first dose applied at the beginning of May.

Different nitrogen fertilization treatments of soil were applied to all plots of the trial. The following ammonium nitrate (containing 33.5\% of $\mathrm{N}$ ) applications, previously described by Wrona [44] were compared to the control without fertilization (N-0): (1) $50 \mathrm{~kg} \mathrm{~N} \cdot \mathrm{ha}^{-1}$ applied to the entire surface of the plot (N-50); (2) $100 \mathrm{~kg} \mathrm{~N} \cdot \mathrm{ha}^{-1}$ applied to the entire surface of the plot (N-100); (3) $50 \mathrm{~kg} \mathrm{~N} \cdot \mathrm{ha}^{-1}$ applied to the entire surface of the plot in early spring and $50 \mathrm{~kg} \mathrm{~N} \cdot \mathrm{ha}^{-1}$ at the end of May (N-50+50); (4) $50 \mathrm{~kg} \mathrm{~N} \cdot \mathrm{ha}^{-1}$ applied to the herbicide strip (N-50h). Each combination was replicated six times on the plots, each consisting of eight randomly distributed trees.

The same practices of pruning and disease and pest control were applied in all management systems in accordance with the standards of integrated pest management. The trees were fertilized in the early spring according to the soil mineral content.

\subsection{Nutritional Status of Leaves and Fruits}

In order to assess the nutritional status of the trees, 50 leaves were randomly collected each year from each plot of trees in the phase of phenological development corresponding to $\mathrm{BBCH}-91$. Under the conditions of the experiment, this occurred at the end of July. Healthy, fully developed leaves were collected from the middle part of the shoot at a height of approximately $150 \mathrm{~cm}$. The collected leaves were taken from the middle part of one-year-old shoots, dried at $70{ }^{\circ} \mathrm{C}$ for $24 \mathrm{~h}$, and ground. The nitrogen content was measured according to the Kjeldahl method [45]. The elements $\mathrm{P}, \mathrm{K}, \mathrm{Mg}$, and Ca were marked using the ICP-AES method with a Thermo Scientific iCAP 6500 Duo spectrometer (Thermo Fischer Scientific, Waltham, MA, USA) after the samples were burnt in the muffle furnace (Czylok, Jatrzębie Zdrój, Poland) at $550{ }^{\circ} \mathrm{C}$ and digested in a $0.5 \mathrm{M}$ solution of $\mathrm{HCl}$. 
From each combination, 10 randomly selected fruits were collected, from which a fragment of the fruit flesh without the peel and seed socket was obtained for testing. Then the collected samples were dried at $70^{\circ} \mathrm{C}$ for $24 \mathrm{~h}$ and ground. The next steps were the same as for assessing the concentration of macroelements in the leaves. These measurements allowed for calculating the leaf and fruit mineral concentrations, which are presented in $\%$ of dry mass (\% d.m.).

\subsection{Mycorrhizal Colonization}

To quantify mycorrhizal colonization, root sampling was conducted sequentially every second year of the experiment at the end of June, which involved extracting samples of the roots with a field spade under each tree from a depth of up to $30 \mathrm{~cm}$. The roots were carefully removed, transferred to the lab, and washed with distilled water, after which the fine roots ( $<1 \mathrm{~mm}$ in diameter) were pooled from each tree and cut into $1 \mathrm{~cm}$ sections.

The mycorrhizal colonization of the roots was visualized using the staining technique described by $[46,47]$ with carbol fuchsin. Microscopic specimens were prepared, each of which represented one plot and consisted of thirty root sections, each one-centimeter long embedded in glycerin, which were then examined with a Leica DM1000 microscope (Leica, Wetzlar, Germany). The assessment of the degree of colonization of the roots by AMF was performed with the Trouvelot method [48]. Based on the results, the mycorrhizal frequency $(\mathrm{F} \%)$, relative mycorrhizal intensity $(\mathrm{M} \%)$, and absolute mycorrhizal intensity (m\%) were calculated using the computer program MYCOCALC (INRA, Dijon, France) [49].

\subsection{Statistical Analysis}

The study was a split-block design with six replications per treatment combination. The statistical analysis was conducted using analysis of variance (ANOVA) tests, and the separation of the mean values was carried out with the Newman-Keuls multiple range test at a significance level of $p<0.05$. The analysis was conducted using the Statistica 13 software package (StatSoft, Cracow, Poland).

\section{Results}

\subsection{Mycorrhizal Parameters}

The statistical data analysis showed that parameters that describe root colonization by AMF depended on the factors used in the experiment. We observed that significant simple effects of the used factors excluded fertilization as well as their interactions (Table 1). Using AMF inoculum significantly increased the mycorrhizal frequency $(F)$ between 2016 and 2020. Similar observations were made for the absolute mycorrhizal intensity (AMI) and relative mycorrhizal intensity (RMI). The values of the tested parameters were higher every period the roots were tested. At the end of the 9-year experiment, all the root samples taken from the inoculated trees presented structures of AMF, while the values of mycorrhizal frequency calculated for the uninoculated trees were approximately $30 \%$ lower; for the AMI and RMI, even higher differences were noted.

\subsection{Leaf Nutrient Status}

The average results for all the years of the experiment show that in the absence of inoculation, the nitrogen fertilization treatments influenced the $\mathrm{N}$ content in the leaves as compared to the untreated control, and the $\mathrm{N}$ content was higher by $11 \%$ with $\mathrm{N}-50+50$ and N50h. The inoculated trees, the unfertilized and the N-50-fertilized, manifested higher average leaf $\mathrm{N}$ contents by about $3 \%$ and $5 \%$, respectively, compared to the uninoculated trees. Such a relationship was not observed with the use of the higher fertilizer doses and the dose applied directly to the herbicide strip (Table 2).

The average results for all the years of the experiment show that in the absence of inoculation, the phosphorus content in the leaves of the unfertilized trees was significantly higher in comparison to those fertilized, by $23.5 \%$ compared to the N-100 treatment. On the other hand, the leaf $\mathrm{P}$ was significantly higher in the inoculated trees compared to the 
M0 trees, regardless of whether the nitrogen regime was applied or not. The increase in the leaf phosphorus absorption under AMF + PGPR conditions ranged from 5\% (at $\mathrm{N}-0$ ) to $23 \%$ (at N-50h). The leaf $\mathrm{P}$ in inoculated tress depended on the $\mathrm{N}$ treatment. The N-100 treatment significantly reduced the $\mathrm{P}$ uptake by leaves in contrast to other $\mathrm{N}$ regimes and N0. The N-50h treatment significantly improved the phosphorus nutrition of the leaves by $9.6 \%$, compared to the N-100 treatment (Table 2).

Table 1. Mycorrhizal frequency (F), absolute mycorrhizal intensity (AMI), and relative mycorrhizal intensity (RMI) of tested apple trees in chosen years of the experiment depending on the year-microbial treatment and nitrogen fertilization. M0: uninoculated; M: inoculated.

\begin{tabular}{|c|c|c|c|c|c|}
\hline \multirow{2}{*}{ Year } & \multirow{2}{*}{ Treatment } & \multirow{2}{*}{ Nitrogen Fertilization } & \multicolumn{3}{|c|}{ Mycorrhizal Parameters (\%) } \\
\hline & & & $\mathbf{F}$ & AMI & RMI \\
\hline \multirow{10}{*}{2012} & \multirow{5}{*}{ M0 } & $\mathrm{N}-0$ & $23.33 \pm 8.82$ & $0.093 \pm 0.05$ & $0.378 \pm 0.11$ \\
\hline & & N-50 & $20.33 \pm 6.69$ & $0.079 \pm 0.04$ & $0.375 \pm 0.11$ \\
\hline & & $\mathrm{N}-100$ & $40.00 \pm 9.96$ & $0.133 \pm 0.05$ & $0.350 \pm 0.13$ \\
\hline & & $N-50+50$ & $27.67 \pm 4.04$ & $0.084 \pm 0.07$ & $0.308 \pm 0.06$ \\
\hline & & N-50h & $24.67 \pm 7.04$ & $0.089 \pm 0.04$ & $0.350 \pm 0.13$ \\
\hline & \multirow{5}{*}{ M } & $\mathrm{N}-0$ & $17.67 \pm 6.94$ & $0.055 \pm 0.03$ & $0.198 \pm 0.03$ \\
\hline & & $\mathrm{N}-50$ & $12.38 \pm 5.18$ & $0.067 \pm 0.08$ & $0.243 \pm 0.07$ \\
\hline & & $\mathrm{N}-100$ & $27.67 \pm 8.57$ & $0.081 \pm 0.02$ & $0.267 \pm 0.03$ \\
\hline & & $N-50+50$ & $32.00 \pm 6.57$ & $0.100 \pm 0.05$ & $0.294 \pm 0.04$ \\
\hline & & N-50h & $14.67 \pm 7.81$ & $0.073 \pm 0.02$ & $0.238 \pm 0.02$ \\
\hline \multirow{10}{*}{2016} & \multirow{5}{*}{ M0 } & $\mathrm{N}-0$ & $27.78 \pm 7.91$ & $0.278 \pm 0.10$ & $1.000 \pm 0.12$ \\
\hline & & $\mathrm{N}-50$ & $28.89 \pm 9.21$ & $0.644 \pm 0.25$ & $2.222 \pm 0.19$ \\
\hline & & $\mathrm{N}-100$ & $31.11 \pm 6.98$ & $1.400 \pm 0.68$ & $4.033 \pm 2.72$ \\
\hline & & $N-50+50$ & $33.33 \pm 6.67$ & $0.511 \pm 0.10$ & $1.600 \pm 0.53$ \\
\hline & & N-50h & $31.11 \pm 8.11$ & $0.489 \pm 0.25$ & $1.489 \pm 0.43$ \\
\hline & \multirow{5}{*}{ M } & $\mathrm{N}-0$ & $51.11 \pm 7.70$ & $5.822 \pm 1.32$ & $11.64 \pm 3.62$ \\
\hline & & $\mathrm{N}-50$ & $44.05 \pm 14.37$ & $3.878 \pm 0.49$ & 7.197.637士 \\
\hline & & $\mathrm{N}-100$ & $37.78 \pm 8.85$ & $2.022 \pm 0.96$ & $5.294 \pm 2.21$ \\
\hline & & $N-50+50$ & $34.44 \pm 5.08$ & $0.967 \pm 0.32$ & $2.822 \pm 0.96$ \\
\hline & & N-50h & $42.23 \pm 9.52$ & $5.044 \pm 1.86$ & $12.13 \pm 5.12$ \\
\hline \multirow{10}{*}{2020} & \multirow{5}{*}{ M0 } & $\mathrm{N}-0$ & $70.00 \pm 8.82$ & $1.100 \pm 0.21$ & $1.564 \pm 0.15$ \\
\hline & & $\mathrm{N}-50$ & $64.44 \pm 7.69$ & $0.822 \pm 0.20$ & $1.269 \pm 0.24$ \\
\hline & & N-100 & $77.78 \pm 18.36$ & $4.511 \pm 3.25$ & $5.086 \pm 2.06$ \\
\hline & & $\mathrm{N}-50+50$ & $65.00 \pm 8.34$ & $1.002 \pm 0.29$ & $1.521 \pm 0.26$ \\
\hline & & N-50h & $72.22 \pm 11.71$ & $1.922 \pm 1.05$ & $2.547 \pm 1.06$ \\
\hline & \multirow{5}{*}{ M } & $\mathrm{N}-0$ & $100.0 \pm 0.00$ & $23.74 \pm 6.82$ & $23.74 \pm 6.82$ \\
\hline & & $\mathrm{N}-50$ & $100.0 \pm 0.00$ & $34.33 \pm 4.26$ & $34.33 \pm 4.26$ \\
\hline & & $\mathrm{N}-100$ & $100.0 \pm 0.00$ & $24.84 \pm 5.96$ & $24.84 \pm 5.96$ \\
\hline & & $N-50+50$ & $100.0 \pm 0.00$ & $36.56 \pm 2.60$ & $36.56 \pm 2.60$ \\
\hline & & N-50h & $100.0 \pm 0.00$ & $34.56 \pm 8.47$ & $34.56 \pm 8.47$ \\
\hline \multicolumn{3}{|c|}{ Year } & $<0.0001$ & $<0.0001$ & $<0.0001$ \\
\hline \multicolumn{3}{|c|}{ Treatment } & $<0.0001$ & $<0.0001$ & $<0.0001$ \\
\hline \multicolumn{3}{|c|}{ Nitrogen fertilization } & 0.5147 & 0.2396 & 0.3096 \\
\hline \multicolumn{3}{|c|}{ Year $\times$ Treatment } & $<0.0001$ & $<0.0001$ & $<0.0001$ \\
\hline \multicolumn{3}{|c|}{ Year $\times$ Nitrogen fertilization } & 0.5921 & 0.02899 & 0.0256 \\
\hline \multicolumn{3}{|c|}{ Treatment $\times$ Nitrogen fertilization } & 0.1889 & 0.0197 & 0.0204 \\
\hline \multicolumn{3}{|c|}{ Year $\times$ Treatment $\times$ Nitrogen fertilization } & 0.7641 & 0.0027 & 0.0026 \\
\hline
\end{tabular}

Note: Bold format highlights significance.

The average results for all the years of the experiment show that in the absence of inoculation, the leaf $\mathrm{K}$ was better absorbed in the unfertilized trees and when $\mathrm{N}-100$ was applied. The microbial-inoculated trees that received N-50, N-50+50, and N-50h expressed significantly higher leaf $\mathrm{K}$ by about $19 \%, 11 \%$, and $14 \%$, respectively, in contrast to the 
uninoculated control. Inoculation had no effect on the $\mathrm{K}$ content when no fertilization was applied (Table 2).

Table 2. Effect of microbial inoculation and nitrogen treatment on nutrient content, expressed in \% of dry mass (\% d.m.) in apple leaves.

\begin{tabular}{|c|c|c|c|c|c|c|}
\hline \multirow{2}{*}{ Treatment } & \multirow{2}{*}{$\begin{array}{c}\text { Nitrogen } \\
\text { Fertilization }\end{array}$} & \multicolumn{5}{|c|}{$\begin{array}{l}\text { Macronutrient } \\
\text { (\% d.m.) }\end{array}$} \\
\hline & & $\mathbf{N}$ & $\mathbf{P}$ & $\mathbf{K}$ & $\mathrm{Mg}$ & $\mathrm{Ca}$ \\
\hline \multirow{5}{*}{ M0 } & $\mathrm{N}-0$ & A $2.17 \pm 0.05 a$ & A $0.204 \pm 0.007 \mathrm{~d}$ & A $1.02 \pm 0.06 \mathrm{~b}$ & A $0.25 \pm 0.01 \mathrm{ab}$ & B $1.74 \pm 0.07 b$ \\
\hline & $N-50$ & A $2.33 \pm 0.03 b$ & A $0.164 \pm 0.004 b$ & $\mathrm{~A} 0.83 \pm 0.04 \mathrm{a}$ & В $0.27 \pm 0.01 \mathrm{~b}$ & B $1.81 \pm 0.05 b$ \\
\hline & N-100 & A $2.24 \pm 0.02$ bc & A $0.156 \pm 0.003 a$ & B $1.04 \pm 0.05 b$ & B $0.25 \pm 0.01 \mathrm{a}$ & A $1.60 \pm 0.04 \mathrm{a}$ \\
\hline & $\mathrm{N}-50+50$ & A $2.40 \pm 0.02 c$ & A $0.176 \pm 0.006 \mathrm{c}$ & $\mathrm{A} 0.82 \pm 0.07 \mathrm{a}$ & A $0.31 \pm 0.02$ c & A $1.73 \pm 0.05 b$ \\
\hline & N-50h & A $2.41 \pm 0.06 \mathrm{c}$ & A $0.169 \pm 0.003$ bc & A $0.83 \pm 0.03 \mathrm{a}$ & B $0.26 \pm 0.01 \mathrm{ab}$ & B $1.76 \pm 0.01 b$ \\
\hline \multirow{5}{*}{ M } & $\mathrm{N}-0$ & B $2.28 \pm 0.02 \mathrm{a}$ & B $0.215 \pm 0.004$ bc & A $1.08 \pm 0.03 b$ & A $0.25 \pm 0.01 \mathrm{a}$ & A $1.62 \pm 0.06$ bc \\
\hline & $N-50$ & B $2.40 \pm 0.03$ c & B $0.210 \pm 0.005 \mathrm{~b}$ & B $1.03 \pm 0.08 \mathrm{~b}$ & A $0.25 \pm 0.01 \mathrm{a}$ & A $1.54 \pm 0.04 \mathrm{c}$ \\
\hline & N-100 & A $2.35 \pm 0.04 b c$ & В $0.198 \pm 0.007$ a & A $0.95 \pm 0.03 \mathrm{ab}$ & A $0.23 \pm 0.01 \mathrm{a}$ & A $1.57 \pm 0.06 b$ \\
\hline & $N-50+50$ & A $2.41 \pm 0.02$ c & B $0.212 \pm 0.005$ bc & В $0.92 \pm 0.05 \mathrm{a}$ & A $0.30 \pm 0.02 \mathrm{~b}$ & A $1.68 \pm 0.04 \mathrm{a}$ \\
\hline & N-50h & A $2.34 \pm 0.03 \mathrm{~b}$ & В $0.219 \pm 0.006$ с & В $0.97 \pm 0.06 \mathrm{ab}$ & A $0.24 \pm 0.01 \mathrm{a}$ & A $1.57 \pm 0.07 b$ \\
\hline
\end{tabular}

Note: Uppercase letters next to the means indicate significant differences between inoculation treatments, and lowercase letters indicate significant differences between nitrogen fertilization within inoculation treatments (at $p \leq 0.05$, according to the Newman-Keuls test). M0: non-inoculated; M: inoculated.

The average results for all the years of the experiment show that in the absence of inoculation, the $\mathrm{N}-50+50$ fertilization treatment contributed to significantly higher leaf $\mathrm{Mg}$ content in comparison to the untreated control and other $\mathrm{N}$ regimes, by a maximum of $19 \%$. Microbial inoculation, in comparison to the untreated control, had no effect on leaf $\mathrm{Mg}$ uptake in the unfertilized or N-50+50-fertilized apple trees. Moreover, at the doses of $\mathrm{N}-50, \mathrm{~N}-100$, and N-50h, microbial inoculation contributed to reduced leaf $\mathrm{Mg}$ uptake by about $8 \%$ when compared to the uninoculated control. Both in the case of the inoculated and uninoculated trees, the best nutritional $\mathrm{Mg}$ status was established with the N-50+50 fertilization treatment (Table 2).

The average results for all the years of the experiment show that the leaf Ca was significantly lower by a maximum of $12 \%$ when the uninoculated trees received N-100 in comparison to the other fertilization treatments. The microbial treatment, in comparison to the uninoculated control, had no effect on the leaf Ca when the N-100 and N-5rr0 treatments were applied, and it significantly decreased the leaf Ca by approximately $7 \%, 15 \%$, and $11 \%$ when the N-0, N-50, and N-50h treatments were applied, respectively (Table 2).

\subsection{Fruit Nutrient Status}

Microbial inoculation, compared to M0, contributed to the reduction of phosphorus absorption in fruits by $6.7 \%$ and $13 \%$, at the doses of N-50 and N-100, respectively (Table 3).

The average results for all the years of the experiment show that in the absence of inoculation, the $\mathrm{K}$ content was higher with the $\mathrm{N}-0$ and at $\mathrm{N}-100$ treatments compared to the other doses. Overall, the K content in the fruit decreased with the use of mycorrhiza, except for the doses of $\mathrm{N}-50+50$ and N-50h, which contributed to higher fruit $\mathrm{K}$ by $8.4 \%$ and $4.3 \%$, respectively, in comparison to the other $\mathrm{N}$ regimes (Table 3 ).

The average results for all the years of the experiment indicate that in the absence of inoculation, the fertilization dose had no effect on the $\mathrm{Mg}$ uptake by the fruit. Microbial inoculation, in comparison to $\mathrm{M} 0$, did not affect the fruit $\mathrm{Mg}$ absorption, except for the N-100 treatment, which contributed to its decline by $14.3 \%$ (Table 3 ).

The average results for all the years of the experiment indicate that in the absence of inoculation, the $\mathrm{N}$ regime had no effect on the fruit $\mathrm{Ca}$. In addition, using inoculum, in comparison to the uninoculated control, did not affect the fruit $\mathrm{Ca}$ absorption, except for the N-100 treatment, which led to its decline by 17.6\% (Table 3). 
Compared to the fruit, the leaves absorbed higher levels of $\mathrm{K}, \mathrm{P}, \mathrm{Mg}$, and Ca regardless of the application of microbial inoculum.

Table 3. Effect of microbial inoculation and nitrogen treatment on nutrient content, expressed in \% of dry mass (\% d.m.) in apple fruits.

\begin{tabular}{|c|c|c|c|c|c|}
\hline \multirow{2}{*}{ Treatment } & \multirow{2}{*}{ Nitrogen Fertilization } & \multicolumn{4}{|c|}{ Macronutrient (\% d.m.) } \\
\hline & & $\mathbf{P}$ & $\mathbf{K}$ & $\mathrm{Mg}$ & $\mathrm{Ca}$ \\
\hline \multirow{5}{*}{ M0 } & $\mathrm{N}-0$ & A $0.063 \pm 0.004 b$ & B $0.633 \pm 0.007 \mathrm{~b}$ & $\mathrm{~A} 0.027 \pm 0.001 \mathrm{a}$ & $\mathrm{A} 0.031 \pm 0.001 \mathrm{a}$ \\
\hline & N-50 & В $0.060 \pm 0.004 b$ & В $0.571 \pm 0.019$ a & A $0.027 \pm 0.001 \mathrm{a}$ & A $0.035 \pm 0.002 \mathrm{a}$ \\
\hline & N-100 & В $0.054 \pm 0.003 \mathrm{a}$ & В $0.655 \pm 0.010 \mathrm{~b}$ & В $0.028 \pm 0.002 \mathrm{a}$ & В $0.034 \pm 0.004 \mathrm{a}$ \\
\hline & $\mathrm{N}-50+50$ & A $0.058 \pm 0.003 \mathrm{ab}$ & A $0.566 \pm 0.010 \mathrm{a}$ & $\mathrm{A} 0.027 \pm 0.001 \mathrm{a}$ & $\mathrm{A} 0.033 \pm 0.002 \mathrm{a}$ \\
\hline & N-50h & A $0.064 \pm 0.003 b$ & A $0.597 \pm 0.007 \mathrm{a}$ & A $0.027 \pm 0.003 \mathrm{a}$ & A $0.036 \pm 0.002 \mathrm{a}$ \\
\hline \multirow{5}{*}{ M } & $\mathrm{N}-0$ & A $0.061 \pm 0.004 b$ & A $0.556 \pm 0.010 \mathrm{~b}$ & A $0.027 \pm 0.001 \mathrm{~b}$ & A $0.035 \pm 0.003 \mathrm{~b}$ \\
\hline & $\mathrm{N}-50$ & $\mathrm{~A} 0.056 \pm 0.004 \mathrm{~b}$ & A $0.521 \pm 0.017 \mathrm{a}$ & A $0.026 \pm 0.001 \mathrm{ab}$ & $\mathrm{A} 0.031 \pm 0.001 \mathrm{ab}$ \\
\hline & N-100 & A $0.047 \pm 0.003 \mathrm{a}$ & A $0.502 \pm 0.023 \mathrm{a}$ & A $0.024 \pm 0.001 \mathrm{a}$ & A $0.028 \pm 0.002 \mathrm{a}$ \\
\hline & $N-50+50$ & A $0.056 \pm 0.003 \mathrm{~b}$ & B $0.618 \pm 0.009 \mathrm{c}$ & A $0.027 \pm 0.001 \mathrm{~b}$ & A $0.033 \pm 0.003 \mathrm{ab}$ \\
\hline & N-50h & A $0.060 \pm 0.001 \mathrm{~b}$ & B $0.624 \pm 0.021 \mathrm{c}$ & A $0.027 \pm 0.001 \mathrm{~b}$ & A $0.034 \pm 0.006 \mathrm{ab}$ \\
\hline
\end{tabular}

Note: Uppercase letters next to the means indicate significant differences between inoculation treatments, and lowercase letters indicate significant differences between nitrogen fertilization within inoculation treatments (at $p \leq 0.05$, according to the Newman-Keuls test). M0: non-inoculated; M: inoculated.

\subsection{Macroelement Partitioning of Leaves and Fruits}

Nutrient partitioning of tree leaves and fruits revealed how inoculation with AMF + PGPR can affect the distribution of macroelements depending on the nitrogen fertilization regime (Figure 1). Potassium and phosphorus macroelement contents were the most affected in terms of partitioning within tested tree organs. In both cases, the plants treated with AMF + PGPR inoculum showed a higher relative concentration of the mentioned macroelements in leaves compared to the control plants, except potassium content noted for N-50+50 and N-50h nitrogen fertilization.
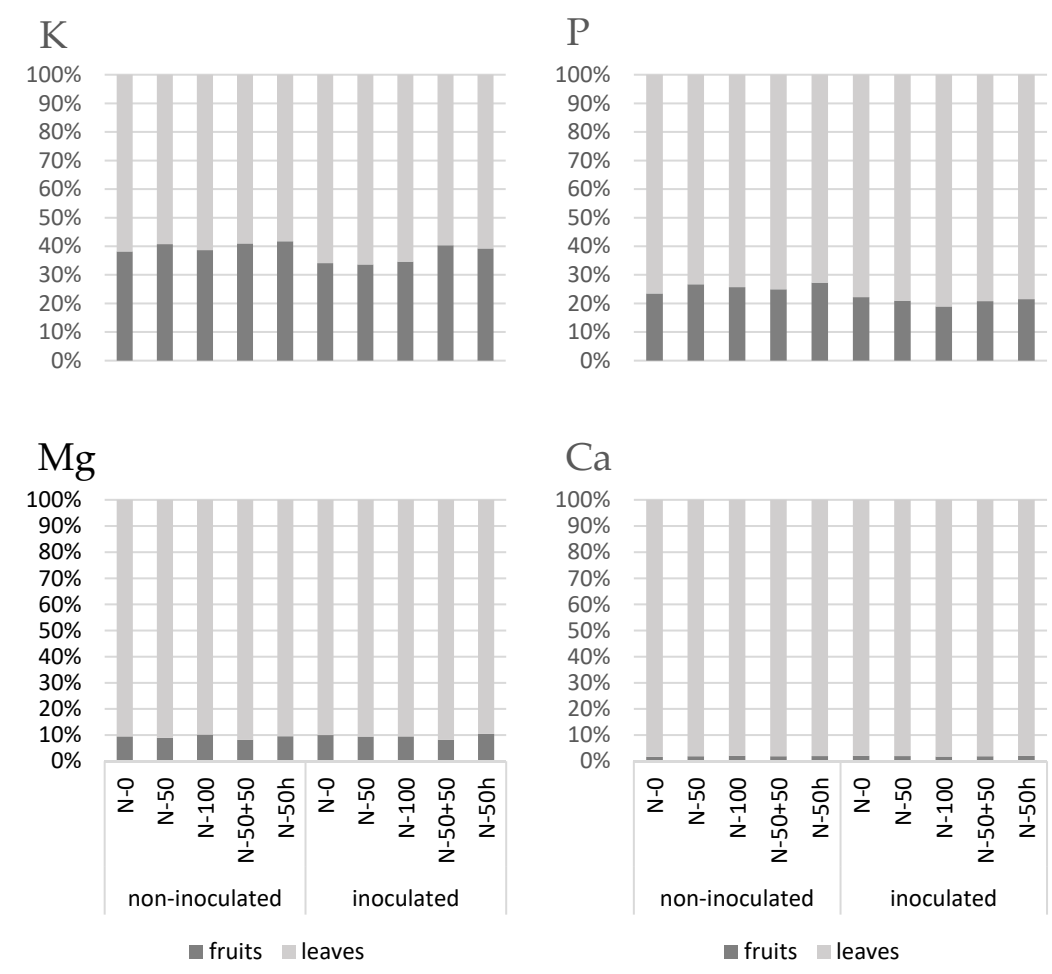

Figure 1. Potassium, phosphorus, magnesium, and calcium partitioning between leaves and fruits depending on the use of microbial inoculum and different nitrogen fertilization levels. 


\subsubsection{Leaves}

Arbuscular mycorrhizal fungi (AMFs) and plant-growth-promoting rhizobacteria (PGPR) contributed to higher phosphorus concentration in leaves, which we also confirmed in terms of nutrient ratios (Figure 2). Under AMF + PGPR inoculation versus the uninoculated control, the ratios of $\mathrm{P}$ to $\mathrm{Ca}$ and $\mathrm{Mg}$ in the leaves that we observed were significantly higher. This relationship also concerned the $\mathrm{P} / \mathrm{N}$ ratio, except for the unfertilized control, where the mycorrhizal treatment had no effect on the P content. The AMFs contributed to significantly higher $\mathrm{P} / \mathrm{K}$ ratios when the N-100 and N-50h doses were applied.

\section{P:K}

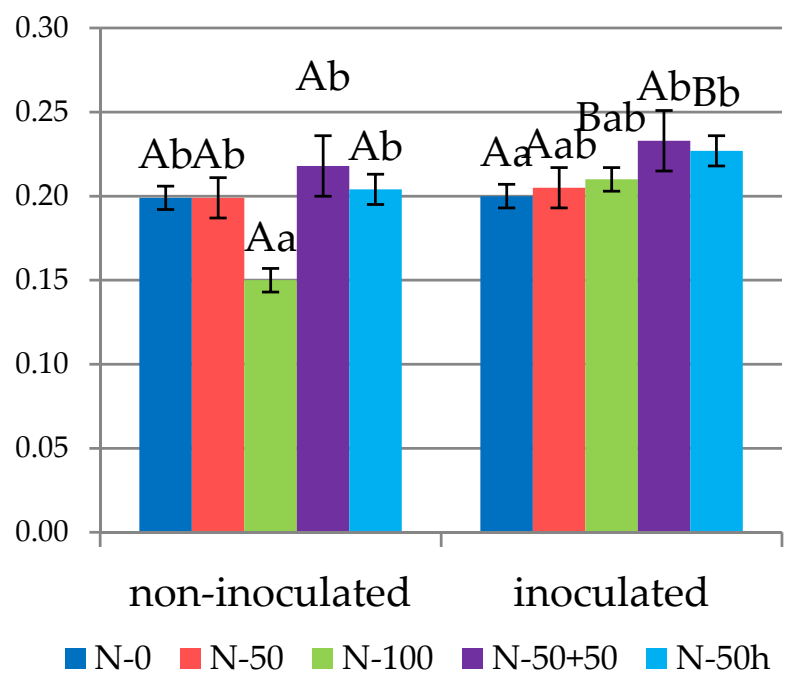

\section{P:Mg}

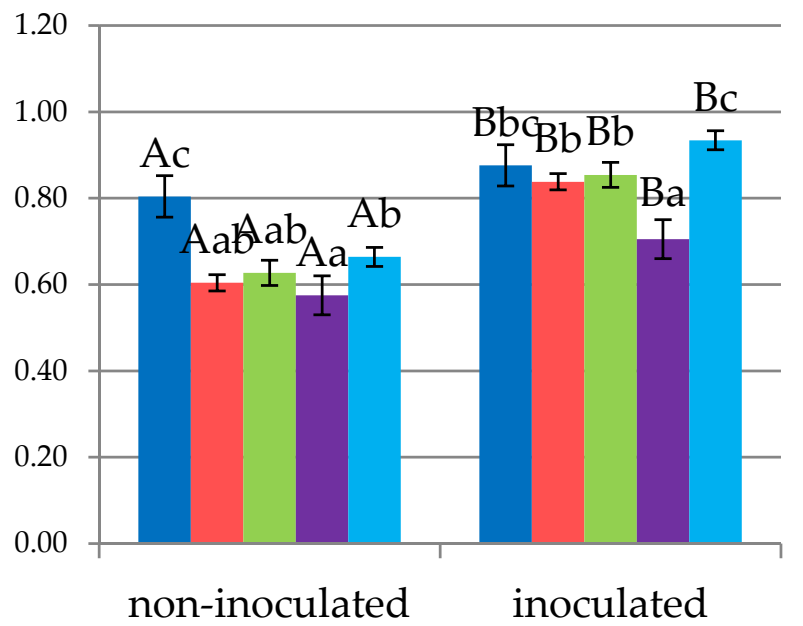

$\square \mathrm{N}-0 \quad \mathrm{~N}-50 \quad \mathrm{~N}-100 \quad \mathrm{~N}-50+50 \quad \mathrm{~N}-50 \mathrm{~h}$

\section{P:Ca}

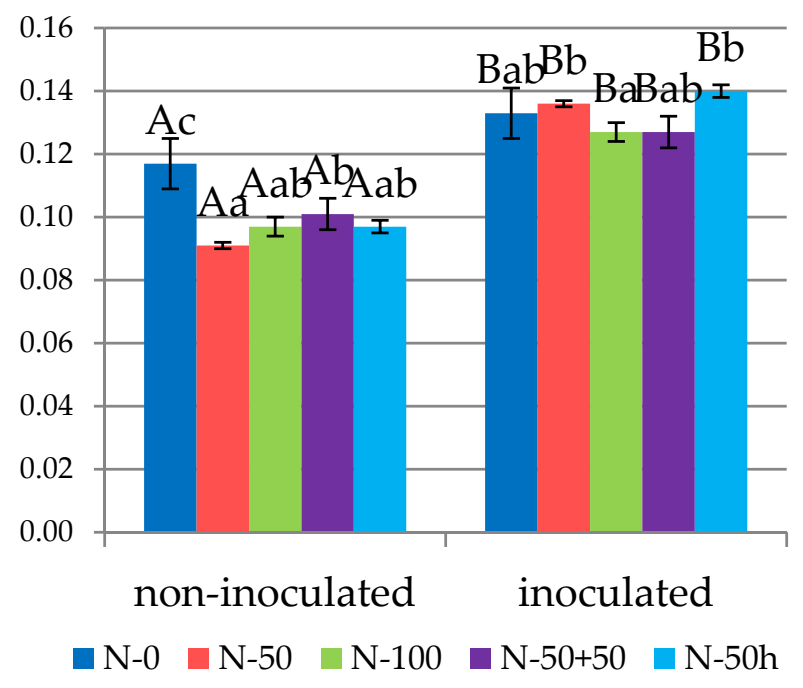

P:N

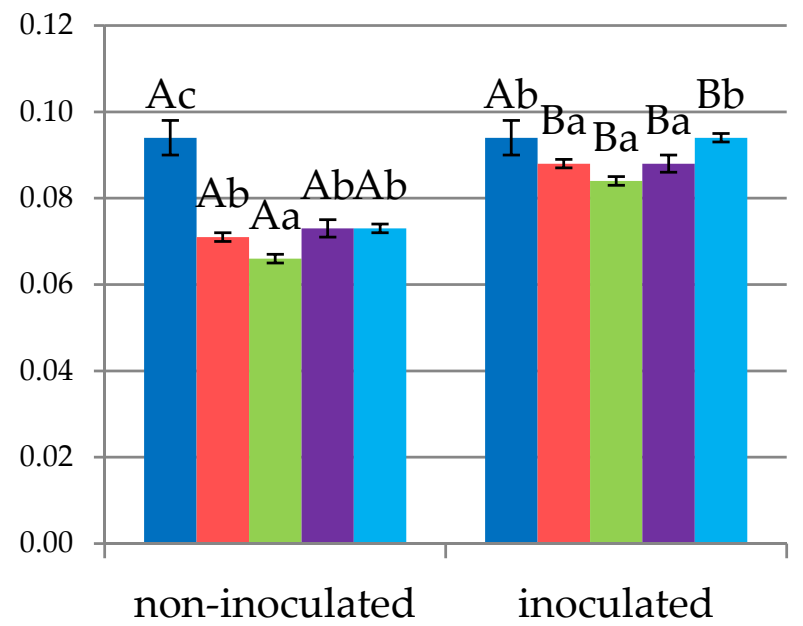

N-0 N-50 N-100 N-50+50 N-50h

Figure 2. Chosen macronutrient ratios for the leaves of the 'Šampion Arno' tree depending on the use of microbial inoculum and different nitrogen fertilization levels. Uppercase letters over bars indicate significant differences between treatments, and lowercase letters indicate significant differences between nitrogen fertilization within treatments (at $p \leq 0.05$, according to the Newman-Keuls test). 


\subsubsection{Fruits}

Microbial inoculation decreased the K/Ca ratio in the fruit of the unfertilized control trees and increased it when the N-50h dose was applied (Figure 3). Mycorrhizal inoculation influenced the $\mathrm{P} / \mathrm{K}$ ratio in fruits depending on the $\mathrm{N}$ fertilization treatment. AMFs increased the provision of $\mathrm{P}$ in the absence of $\mathrm{N}$ fertilization and with the $\mathrm{N}-100$ dose, and decreased $\mathrm{P}$ when the $\mathrm{N}-50+50$ and $\mathrm{N}-50 \mathrm{~h}$ treatments were applied. Using AMF inoculum affected the $\mathrm{P} / \mathrm{Mg}$ ratios in the fruits (Figure 3). Higher values of this parameter were noted for plants treated with AMF + PGPR inoculum. AMF + PGPR increased the K/Ca ratio in fruits with the $\mathrm{N}-50 \mathrm{~h}$ treatment and reduced the ratio for the $\mathrm{N}-0$ treatment in comparison to the uninoculated control (Figure 3).

\section{$\mathrm{P}: \mathrm{K}$}

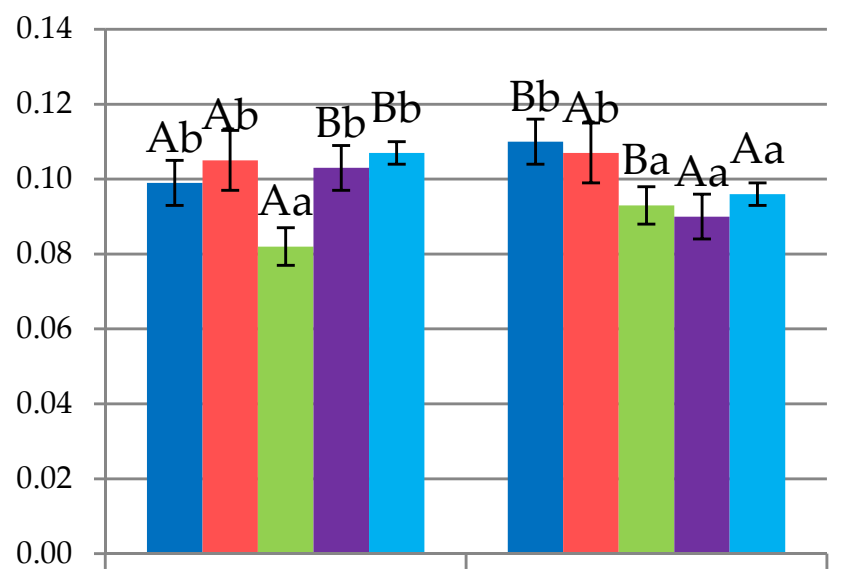

non-inoculated inoculated
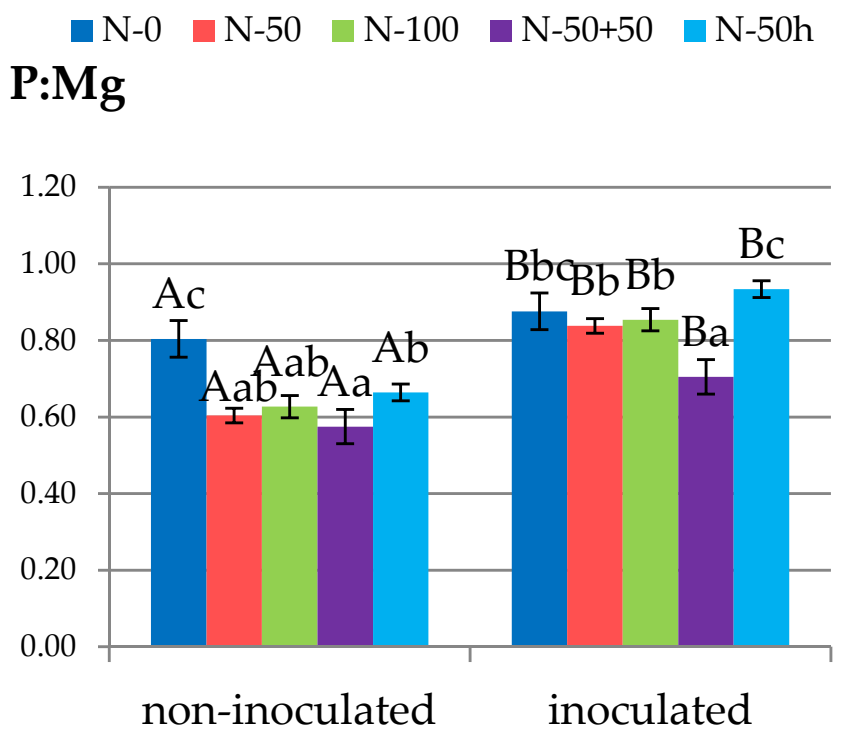

$\square \mathrm{N}-0 \quad \mathrm{~N}-50 \quad \square \mathrm{N}-100 \quad \square \mathrm{N}-50+50 \quad$ N-50h

\section{P:Ca}
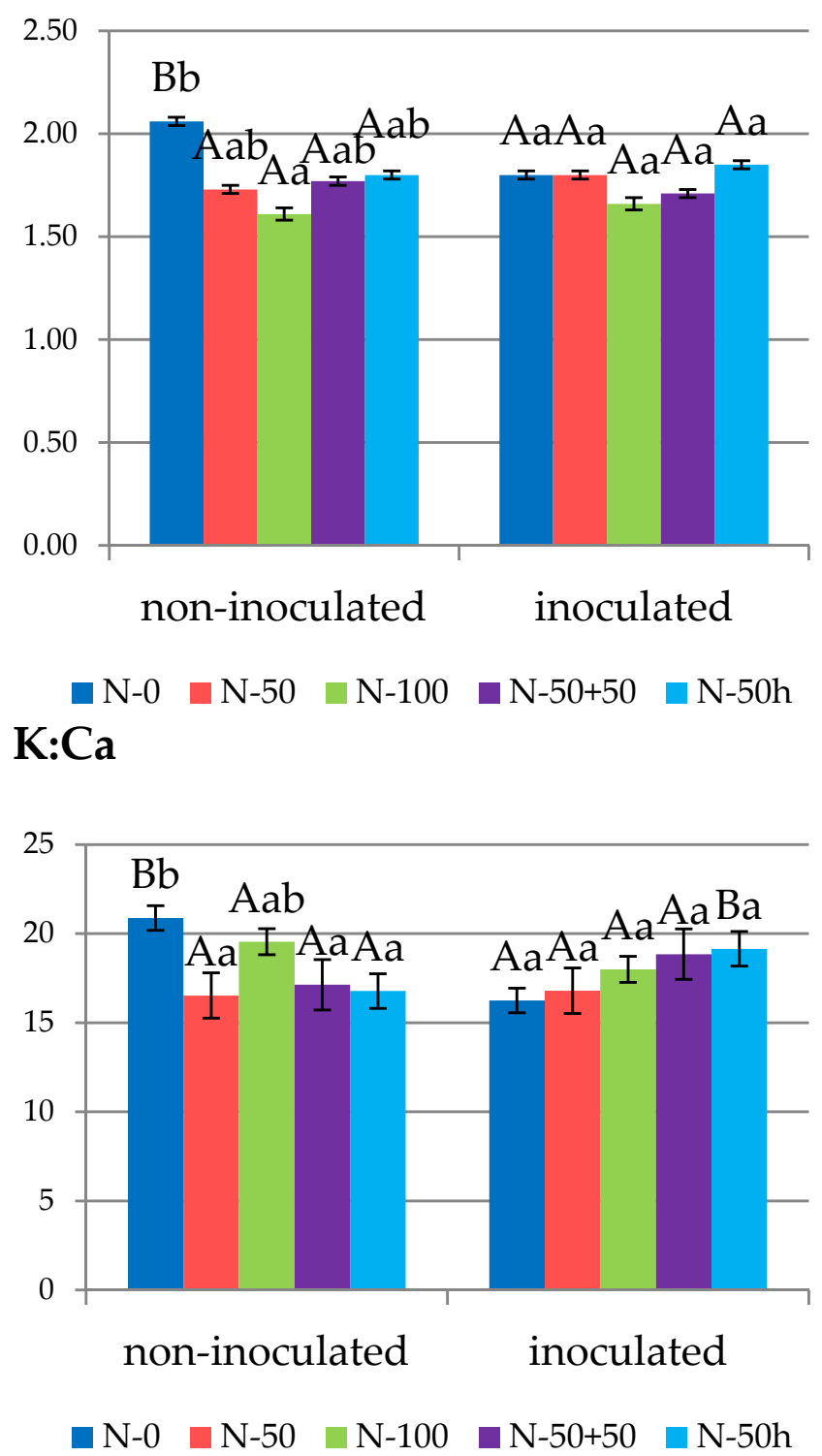

Figure 3. Chosen macronutrients ratios for the fruits of the 'Šampion Arno' tree depending on the use of microbial inoculum and different nitrogen fertilization. Uppercase letters over bars indicate significant differences between treatments, and lowercase letters indicate significant differences between nitrogen fertilization within treatments (at $p \leq 0.05$, according to the Newman-Keuls test). 


\section{Discussion}

It has been found that under Mediterranean climatic conditions, microbial inoculation significantly increases the P and $\mathrm{Zn}$ uptake by different fruit tree species [42,43]. Plant growth and nutrient uptake are strongly dependent on AMF inoculation, which also helps to reinstate soil quality. Mycorrhizal-inoculated plants had high shoot and root dry weights and greater nutrient uptake than the non-mycorrhizal plantlets [42,43]. The authors of [50] noticed that at low soil P levels, arbuscular mycorrhizal fungi inoculation had a significant positive effect on the growth of the perennial tree Jatropha curcas L., its shoot and root dry matter content, plant height, number of leaves, total leaf area, leaf area per leaf, and the Dickson quality index. The root/shoot ratio and the leaf area ratio were also affected by mycorrhizal inoculation and the level of added P. Physic nut plants exhibited high mycorrhizal dependency on added soil P up to $50 \mathrm{mg} \mathrm{kg}^{-1}$ [50].

In our research, the inoculation of unfertilized and N-50-fertilized trees improved the absorption of $\mathrm{N}$ in leaves. However, the use of mycorrhiza in combination with the highest nitrogen doses did not influence nitrogen absorption. We conclude that such high doses are not justified in supplying the leaves with nitrogen, and better results are obtained when lower doses are used in conjunction with AMF inoculation.

The authors of [51] showed that phosphorus and nitrogen are the major nutritional determinants of the interactions between plants and soil fungi. The symbiosis-promoting effect of nitrogen starvation dominantly overruled the suppressive effect of high phosphorus nutrition onto arbuscular mycorrhiza, suggesting that plants promote the symbiosis as long as they are limited by one of the two major nutrients [51]. The results of this study show that AMF + PGPR inoculation improved P leaf uptake regardless of whether the nitrogen regime was applied or not. It has already been proven that AMFs alleviate phosphorus limitation by reducing the plant $\mathrm{N} / \mathrm{P}$ ratios under warming and the addition of nitrogen addition, and they increase available soil $\mathrm{P}$ concentrations, promoting plant $P$ absorption under global change [52]. The authors of [53] showed that when AMFs and cotton were symbiotic, the expression of the specific phosphate transporter family genes and the $\mathrm{P}$ concentration in the cotton biomass were significantly enhanced. In addition, in our experiment, AMF symbiosis significantly increased the available soil $\mathrm{P}$ concentrations, promoting the $\mathrm{P}$ absorption in leaves and increasing the leaf $\mathrm{P} / \mathrm{N}$ ratios. The results show that the leaf $\mathrm{P}$ in inoculated trees depended on the $\mathrm{N}$ treatment. The highest dosage of $\mathrm{N}+100$ significantly reduced the $\mathrm{P}$ uptake by leaves, in contrast to the other $\mathrm{N}$ regimes and $\mathrm{N} 0$. It has been found that nitrogen-induced acidification, not $\mathrm{N}$ nutrients, dominates the suppressive $\mathrm{N}$ effects on arbuscular mycorrhizal fungi [54]. In our study, low to moderate $\mathrm{N}$ inputs increased the AMF parameters, corresponding to the increasing N/P ratio. Structural equation modeling showed that while the soil $\mathrm{N} / \mathrm{P}$ stoichiometry primarily controlled the effect of added $\mathrm{P}$ on AMFs, $\mathrm{N}$-induced soil acidity overtook the $\mathrm{N} / \mathrm{P}$ stoichiometry under high $\mathrm{N}$ inputs and dominated the effects of reactive $\mathrm{N}$ on AMFs [54]. 
We also found that AMF + PGPR symbiosis determined the improved K leaf uptake, depending on the nitrogen treatment. However, in our experiment, the highest nitrogen dose of N-100 contributed to reduced K leaf absorption. The authors of [55] demonstrated that $\mathrm{K}$ and $\mathrm{P}$, individually and in combination, significantly influenced the transport of radiocesium by $\mathrm{AMFs}$ to the plant tissue. Whilst an increased concentration of $\mathrm{K}$ decreased the amount of radiocesium transported, the opposite was observed for P. The ecological impact of AMF interactions with microorganisms involved in potassium solubilization is not well resolved compared to those involved in phosphate solubilization. Although direct studies on the interactions between AMFs and potassium-solubilizing microorganisms (KSMs) on plant growth are limited, studies on plant growth-promoting microorganisms (PGPMs) and AMFs do involve organisms with K-solubilizing capabilities. Evidence does exist on the influence of KSMs on mycorrhizal formation and function. Interactions between AMFs and KSMs are vital in sustainable low-input crop production systems that rely on biological processes to achieve improved plant growth and yield, in addition to maintaining soil fertility [56].

\section{Conclusions}

The results of our study show which doses of nitrogen fertilization, or the lack thereof, improve the nutrient supply of plants in the presence of mycorrhiza and PGPR. Nitrogen used at medium doses (N-50 and N-50h) under microbial inoculation significantly increased the concentration of phosphorus $(\mathrm{P})$, and potassium $(\mathrm{K})$ in leaves up to $23 \%$, and $19 \%$, respectively.

On the other hand, under microbial inoculation conditions, the highest nitrogen dose (N-100) diminished the leaf phosphorus content in comparison to other $\mathrm{N}$ regimes, by a maximum of $9.6 \%$. Symbiosis positively conditioned the $\mathrm{K}$ in fruits under $\mathrm{N}-50+50$ and $\mathrm{N}-50 \mathrm{~h}$, increasing the concentration by approximately $4 \%$ and $8 \%$, respectively.

The results also encourage the future exploration of AMF and PGPR effects on apple yield and fruit quality.

Author Contributions: Conceptualization, K.Ł.B., S.P. and D.W.; funding acquisition, D.W.; investigation, S.P.; methodology, S.P. and D.W.; visualization, K.Ł.B. and S.P.; supervision, D.W.; writingoriginal draft, K.Ł.B. and S.P.; writing-review and editing, K.Ł.B., S.P. and D.W. All authors have read and agreed to the published version of the manuscript.

Funding: This research was funded by the Polish Ministry of Science and Higher Education with funds from the Institute of Horticultural Sciences.

Institutional Review Board Statement: Not applicable.

Informed Consent Statement: Not applicable.

Data Availability Statement: The data is contained within the article.

Acknowledgments: The authors would like to thank Jacek Marszał (Department of Pomology, Institute of Horticultural Sciences, Warsaw University of Life Sciences-WULS) for his participation in the experiment.

Conflicts of Interest: The authors declare no conflict of interest. 


\section{Appendix A}

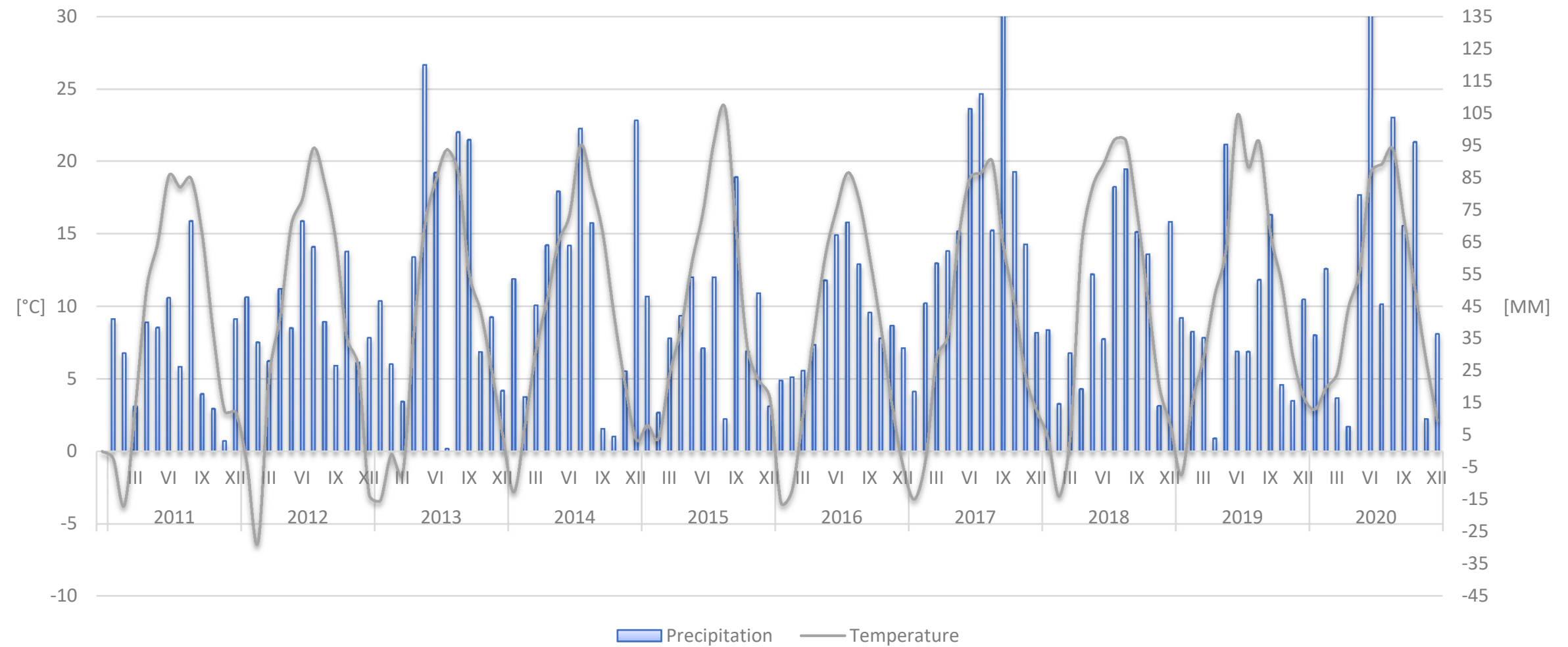

Figure A1. Weather conditions on the experimental site during 2011-2020. 


\section{References}

1. Martin, M.H.; Marschner, H. The Mineral Nutrition of Higher Plants. J. Ecol. 1988, 76, 1250. [CrossRef]

2. Epstein, E.; Bloom, A. Mineral Nutrition of Plants: Principles and Perspectives, 2nd ed.; Sinauer Associates, Inc.: Sunderland, MA, USA, 2005.

3. Galloway, J.N.; Cowling, E.B. Reactive nitrogen and the world: 200 years of change. Ambio 2002, 31, 64-71. [CrossRef]

4. Fernandez, M.S.; Rosiello, R.O.P. Mineral nitrogen in plant physiology and plant nutrition. Crit. Rev. Plant Sci. 1995, 14, 111-148. [CrossRef]

5. Galloway, J.N.; Aber, J.D.; Erisman, J.W.; Seitzinger, S.P.; Howarth, R.; Cowling, E.B.; Cosby, B.J. The Nitrogen Cascade. BioScience 2003, 53, 341-356. [CrossRef]

6. Tilman, D.; Cassman, K.G.; Matson, P.A.; Naylor, R.; Polasky, S. Agricultural sustainability and intensive production practices. Nature 2002, 418, 671-677. [CrossRef] [PubMed]

7. Environmental Defense Fund. The Case for Reforming Farm Programs to Preserve the Environment and Help Family Farmers, Ranchers, and Foresters; Environmental Defense Fund: Washington, DC, USA, 2001.

8. Elser, J.J.; Bennett, E.M.B.M. A broken biogeochemical cycle. Nat. Cell Biol. 2011, 478, 29-31. [CrossRef] [PubMed]

9. Tubiello, F.N.; Salvatore, M.; Ferrara, A.F.; House, J.; Federici, S.; Rossi, S.; Biancalani, R.; Golec, R.D.C.; Jacobs, H.; Flammini, A.; et al. The Contribution of Agriculture, Forestry and other Land Use activities to Global Warming, 1990. Glob. Chang. Biol. 2015, 21, 2655-2660. [CrossRef] [PubMed]

10. Bauer, S.E.; Tsigaridis, K.; Miller, R. Significant atmospheric aerosol pollution caused by world food cultivation. Geophys. Res. Lett. 2016, 43, 5394-5400. [CrossRef]

11. Tilman, D.; Clark, M.; Williams, D.; Kimmel, K.; Polasky, S.; Packer, D.T.K.K.S.P.C. Future threats to biodiversity and pathways to their prevention. Nat. Cell Biol. 2017, 546, 73-81. [CrossRef]

12. Kramer, S.B.; Reganold, J.P.; Glover, J.D.; Bohannan, B.J.M.; Mooney, H.A. Reduced nitrate leaching and enhanced denitrifier activity and efficiency in organically fertilized soils. Proc. Natl. Acad. Sci. USA 2006, 103, 4522-4527. [CrossRef]

13. Mulvaney, R.L.; Khan, S.A.; Ellsworth, T.R. Synthetic Nitrogen Fertilizers Deplete Soil Nitrogen: A Global Dilemma for Sustainable Cereal Production. J. Environ. Qual. 2009, 38, 2295-2314. [CrossRef] [PubMed]

14. Russell, A.E.; Cambardella, C.A.; Laird, D.A.; Jaynes, D.B.; Meek, D.W. Nitrogen fertilizer effects on soil carbon balances in Midwestern U.S. agricultural systems. Ecol. Appl. 2009, 19, 1102-1113. [CrossRef]

15. Robertson, G.P.; Bruulsema, T.W.; Gehl, R.J.; Kanter, D.; Mauzerall, D.L.; Rotz, C.A.; Williams, C.O. Nitrogen-climate interactions in US agriculture. Biogeochemistry 2013, 114, 41-70. [CrossRef]

16. Collins, H.P.; Rasmussen, P.E.; Douglas, C.L., Jr. Croprotation and residue management effect on soil carbon andmicrobial dynamics. Soil Sci. Soc. Am. J. 1992, 56, 783-788. [CrossRef]

17. Lovell, R.D.; Jarvis, S.C.; Bardgett, R.S. Soil microbialbiomass and activity in long-term grassland: Effects of man-agement changes. Soil Biol. Biochem. 1995, 27, 969-975. [CrossRef]

18. Schnurer, J.; Clarholm, M.; Rosswall, T. Microbial bio-mass and activity in agricultural soil with different organicmatter contents. Soil Biol. Biochem. 1985, 17, 611-618. [CrossRef]

19. Anderson, T.; Domsch, K.H. Ratios of microbial biom-ass carbon to total organic carbon in arable soils. Soil Biol. Biochem. 1989, 21, 471-479. [CrossRef]

20. Ross, D.J.; Tate, K.R. Microbial C and N, and respira-tory activity in litter and soil of southern Beech (Nothofa-gus) forest: Distribution and properties. Soil Biol. Biochem. 1993, 25, 477-483. [CrossRef]

21. Raj, H.; Sharma, S. Integration of soil solarization and chemical sterilization with beneficial microorganisms for the control of white root rot and growth of nursery apple. Sci. Hortic. 2009, 119, 126-131. [CrossRef]

22. Krishna, H.; Das, B.; Attri, B.L.; Grover, M.; Ahmed, N. Suppression of Botryosphaeria canker of apple by arbuscular mycorrhizal fungi. Crop. Prot. 2010, 29, 1049-1054. [CrossRef]

23. Miller, D.D.; Domoto, P.A.; Walker, C. Mycorrhizal Fungi at Eighteen Apple Rootstock Plantings in The United States. New Phytol. 1985, 100, 379-391. [CrossRef]

24. An, Z.; Shen, T.; Wang, H. Mycorrhizal fungi in relation to growth and mineral nutrition of apple seedlings. Sci. Hortic. 1993, 54, 275-285. [CrossRef]

25. Matsubara, Y.-I.; Karikomi, T.; Ikuta, M.; Hori, H.; Ishikawa, S.; Harada, T. Effect of Arbuscular Mycorrhizal Fungus Inoculation on Growth of Apple (Malus ssp.) Seedlings. J. Jpn. Soc. Hortic. Sci. 1996, 65, 297-302. [CrossRef]

26. Forge, T.; Muehlchen, A.; Hackenberg, C.; Neilsen, G.; Vrain, T. Effects of preplant inoculation of apple (Malus domestica Borkh.) with arbuscular mycorrhizal fungi on population growth of the root-lesion nematode, Pratylenchus penetrans. Plant Soil 2001, 236, 185-196. [CrossRef]

27. Berdeni, D.; Cotton, T.E.A.; Daniell, T.J.; Bidartondo, M.I.; Cameron, D.; Evans, K.L. The Effects of Arbuscular Mycorrhizal Fungal Colonisation on Nutrient Status, Growth, Productivity, and Canker Resistance of Apple (Malus pumila). Front. Microbiol. 2018, 9, 1461. [CrossRef]

28. Öpik, M.; Moora, M.; Liira, J.; Zobel, M. Composition of root-colonizing arbuscular mycorrhizal fungal communities in different ecosystems around the globe. J. Ecol. 2006, 94, 778-790. [CrossRef]

29. Smith, S.E.; Read, D. Mycorrhizal Symbiosis; Academic Press: Cambridge, MA, USA, 2008. 
30. Thirkell, T.J.; Charters, M.D.; Elliott, A.J.; Sait, S.M.; Field, K.J. Are mycorrhizal fungi our sustainable saviours? Considerations for achieving food security. J. Ecol. 2017, 105, 921-929. [CrossRef]

31. Fester, T.; Sawers, R. Progress and Challenges in Agricultural Applications of Arbuscular Mycorrhizal Fungi. Crit. Rev. Plant Sci. 2011, 30, 459-470. [CrossRef]

32. Miozzi, L.; Vaira, A.M.; Catoni, M.; Fiorilli, V.; Accotto, G.P.; Lanfranco, L. Arbuscular Mycorrhizal Symbiosis: Plant Friend or Foe in the Fight Against Viruses? Front. Microbiol. 2019, 10, 1238. [CrossRef] [PubMed]

33. Bahadur, A.; Batool, A.; Nasir, F.; Jiang, S.; Mingsen, Q.; Zhang, Q.; Pan, J.; Liu, Y.; Feng, H. Mechanistic Insights into Arbuscular Mycorrhizal Fungi-Mediated Drought Stress Tolerance in Plants. Int. J. Mol. Sci. 2019, 20, 4199. [CrossRef] [PubMed]

34. Daei, G.; Ardekani, M.; Rejali, F.; Teimuri, S.; Miransari, M. Alleviation of salinity stress on wheat yield, yield components, and nutrient uptake using arbuscular mycorrhizal fungi under field conditions. J. Plant Physiol. 2009, 166, 617-625. [CrossRef] [PubMed]

35. Zhou, Y.; Li, X.; Gao, Y.; Liu, H.; Gao, Y.; van der Heijden, M.G.A.; Ren, A. Plant endophytes and arbuscular mycorrhizal fungi alter plant competition. Funct. Ecol. 2018, 32, 1168-1179. [CrossRef]

36. Zhang, Y.-C.; Wang, P.; Wu, Q.-H.; Zou, Y.-N.; Bao, Q.; Wu, Q.-S. Arbuscular mycorrhizas improve plant growth and soil structure in trifoliate orange under salt stress. Arch. Agron. Soil Sci. 2016, 63, 491-500. [CrossRef]

37. De Novais, C.B.; Sbrana, C.; Jesus, E.D.C.; Rouws, L.F.M.; Giovannetti, M.; Avio, L.; Siqueira, J.O.; Júnior, O.J.S.; Da Silva, E.M.R.; De Faria, S.M. Mycorrhizal networks facilitate the colonization of legume roots by a symbiotic nitrogen-fixing bacterium. Mycorrhiza 2020, 30, 389-396. [CrossRef]

38. Piazza, G.; Ercoli, L.; Nuti, M.; Pellegrino, E. Interaction Between Conservation Tillage and Nitrogen Fertilization Shapes Prokaryotic and Fungal Diversity at Different Soil Depths: Evidence From a 23-Year Field Experiment in the Mediterranean Area. Front. Microbiol. 2019, 10, 2047. [CrossRef] [PubMed]

39. Treseder, K.K. A meta-analysis of mycorrhizal responses to nitrogen, phosphorus, and atmospheric $\mathrm{CO}_{2}$ in field studies. New Phytol. 2004, 164, 347-355. [CrossRef]

40. Egerton-Warburton, L.M.; Johnson, N.C.; Allen, E.B. Mycorrhizal Community Dynamics Following Nitrogen Fertilization: A Cross-Site Test in Five Grasslands. Ecol. Monogr. 2007, 77, 527-544. [CrossRef]

41. Marklein, A.R.; Houlton, B.Z. Nitrogen inputs accelerate phosphorus cycling rates across a wide variety of terrestrial ecosystems. New Phytol. 2012, 193, 696-704. [CrossRef]

42. Ortas, I. Mycorrhizal species significantly increase citrus yield and nutrient concentration under field conditions. Acta Hortic. 2018, 1217, 171-178. [CrossRef]

43. Ortas, I. Role of mycorrhizae on mineral nutrition of fruit trees. Acta Hortic. 2018, 1217, 271-284. [CrossRef]

44. Wrona, D. Effect of nitrogen fertilization on growth, cropping and fruit quality of 'Šampion' apple trees during 9 years after planting. Folia Hortic. 2004, 16, 55-60.

45. Kjeldahl, J. Neue Methode zur Bestimmung des Stickstoffs in organischen Körpern. Anal. Bioanal. Chem. 1883, 22, 366-382. [CrossRef]

46. Derkowska, E.; Paszt, L.S.; Sumorok, B.; Dyki, B. Colonisation of apple and blackcurrant roots by arbuscular mycorrhizal fungi following mycorrhisation and the use of organic mulches. Folia Hortic. 2013, 25, 117-122. [CrossRef]

47. Derkowska, E.; Paszt, L.S.; Dyki, B.; Sumorok, B. Assessment of Mycorrhizal Frequency in the Roots of Fruit Plants Using Different Dyes. Adv. Microbiol. 2015, 5, 54-64. [CrossRef]

48. Trouvelot, A.; Kough, J.L.; Gianinazzi-Pearson, V. Mesure du Taux de Mycorhization VA d'un Systemeradiculaire. Recherche de Methods D'estimation Avant une Signification Fonctionnelle. In Physiological and Genetical Aspects of Mycorrhizae, 1st ed.; Gia-ninazzi-Pearson, V., Gianinazzi, S., Eds.; INRA: Paris, France, 1986; pp. 217-221.

49. Przybyłko, S.; Kowalczyk, W.; Wrona, D. The Effect of Mycorrhizal Fungi and PGPR on Tree Nutritional Status and Growth in Organic Apple Production. Agronomy 2021, 11, 1402. [CrossRef]

50. Balota, E.L.; Machineski, O.; Truber, P.V.; Scherer, A.; De Souza, F.S. Physic nut plants present high mycorrhizal dependency under conditions of low phosphate availability. Braz. J. Plant Physiol. 2011, 23, 33-44. [CrossRef]

51. Nouri, E.; Breuillin-Sessoms, F.; Feller, U.; Reinhardt, D. Phosphorus and Nitrogen Regulate Arbuscular Mycorrhizal Symbiosis in Petunia hybrida. PLoS ONE 2014, 9, e90841. [CrossRef]

52. Mei, L.; Yang, X.; Zhang, S.; Zhang, T.; Guo, J. Arbuscular mycorrhizal fungi alleviate phosphorus limitation by reducing plant $\mathrm{N}: \mathrm{P}$ ratios under warming and nitrogen addition in a temperate meadow ecosystem. Sci. Total. Environ. 2019, 686, 1129-1139. [CrossRef]

53. Gao, X.; Guo, H.; Zhang, Q.; Guo, H.; Zhang, L.; Zhang, C.; Gou, Z.; Liu, Y.; Wei, J.; Chen, A.; et al. Arbuscular mycorrhizal fungi (AMF) enhanced the growth, yield, fiber quality and phosphorus regulation in upland cotton (Gossypium hirsutum L.). Sci. Rep. 2020, 10, 2084. [CrossRef]

54. Pan, S.; Wang, Y.; Qiu, Y.; Chen, D.; Zhang, L.; Ye, C.; Guo, H.; Zhu, W.; Chen, A.; Xu, G.; et al. Nitrogen-induced acidification, not N-nutrient, dominates suppressive N effects on arbuscular mycorrhizal fungi. Glob. Chang. Biol. 2020, 26, 6568-6580. [CrossRef] 
55. Gyuricza, V.; De Boulois, H.D.; Declerck, S. Effect of potassium and phosphorus on the transport of radiocesium by arbuscular mycorrhizal fungi. J. Environ. Radioact. 2010, 101, 482-487. [CrossRef] [PubMed]

56. Priyadharsini, P.; Muthukumar, T. Interactions between arbuscular mycorrhizal fungi and potassium-solubilizing microorganisms on agricultural productivity. In Potassium Solubilizing Microorganisms for Sustainable Agriculture; Meena, V.S., Maurya, B.R., Verma, J.P., Meena, R.S., Eds.; Springer: New Delhi, India, 2016; pp. 111-125. ISBN 978-81-322-2774-8. [CrossRef] 